\title{
Chinese Fort Creolization: on the Origin of Xining Mandarin
}

\author{
Daniel Bell \\ PhD student, School of English Literature, Language and Linguistics, \\ Newcastle University, Newcastle upon Tyne, UK \\ d.m.bell@pm.me
}

\begin{abstract}
Xining Mandarin (Qinghai province, Northwest China) strikingly diverges from the usual syntactic profile of Sinitic languages, featuring an array of head-final categories which are inherent instead to the local substrate languages. In this paper, the formation of the dialect is considered from a historical perspective and it is seen to have emerged in a fort creolization (Bickerton, 1988) scenario, comparable to that found for European lexifier creoles along the West African coast. Linguistically relevant aspects of the socio-historical scenario underlying the dialect are reconstructed and Xining Mandarin is argued to have formed as the language of Ming dynasty Chinese colonists was acquired imperfectly due to poor access to Chinese among the local population. The speed of creolization and the role of language shift is evaluated, and it is argued that Ming creolization was gradual (rather than abrupt), reflecting cases of fort creolization elsewhere in the world.
\end{abstract}

\section{Keywords}

fort creoles - syntactic change - language shift - Xining Mandarin

\section{$1 \quad$ Introduction}

This paper is concerned with the origin of the regional Chinese language spoken in and around Xining, the capital city of Qinghai province (hereafter, "Xining Mandarin"). In view of their conspicuously non-Sinitic syntax (discussed in 
Section 2 below), contact languages in Qinghai and neighbouring Gansu province with a (predominantly) Chinese lexicon have been referred to as creolized or as - in one sense or another - 'creoles' in various studies, sometimes also with reference to the concept of 'mixed languages' (e.g., a.o. Dwyer, 1992; Muysken and Smith, 1995; Li, 1995: 146; Lee-Smith, 1996b; Zhou, 2013: 403; Sandman, 2018; on Xining Mandarin, Dede, 2003: 345). ${ }^{1}$ However, so far little attention has been paid to the type of creolization in these languages, and in particular to how their formation compares to more familiar cases of European lexifier creolization elsewhere in the world. As we shall see in this paper, Xining Mandarin possesses the following general properties associated with creoles, where 'creoles' are conceived of not as a qualitatively distinct class of language, but by the way in which they combine - in differing ways - properties found in various types of contact scenario (cf. Muysken, 2016):

a) The dialect evidences substantial restructuring from its lexifier (Chinese). Xining Mandarin is a language with head-final syntax across the clausal hierarchy (in contrast to head-initial devices found in Standard Mandarin and other Chinese dialects).

b) Accordingly, like creoles elsewhere, Xining Mandarin is not 'genetically related' to an antecedent language - in the sense that it cannot be said to have arisen through normal transmission (Thomason and Kaufman, 1988) of the lexifier, Chinese, nor via normal transmission of the substrate Mongolic, Tibetan and Turkic languages.

c) It arose in a region where the lexifier language, Chinese, was not spoken as a native language (beyond the Western frontier of the Ming Chinese empire). Like other creoles, it thus shows the property of 'displacement', which Muysken (2016) notes is a necessary condition for classification as a creole. Typically, this displacement was a result of European colonial expansion; here, we shall see that it was the result of Chinese colonization.

d) It emerged as a lingua franca meeting the needs of speakers of local languages to communicate with Chinese-speaking immigrants and was gradually nativized (eventually it became - as it is today - a mother tongue spoken alongside the languages of the indigenous peoples, as well as the mother tongue of those who identify themselves as descendants of the original Chinese immigrants to the region).

1 On the basis of the standardly applied criteria in Chinese dialectology, which are phonological and lexical (not syntactic), Xining Mandarin is classified as a Mandarin Chinese dialect (belonging to the Central Plains group) (e.g., Dede, 2003: 330). However, it diverges from the syntactic norms of Sinitic languages (Sinitic being a technical term for Chinese languages in the Sino-Tibetan language family). 
e) The original time of genesis for Xining Mandarin can be identified with a fair degree of precision (as discussed in Section cmos (15) 9.30. 3, it originated in a contact scenario that began to take shape in the late $14^{\text {th }}$ and early $15^{\text {th }}$ century, when Chinese speakers began to immigrate into a region populated by speakers of Mongolic, Tibetan and Turkic languages).

f) The early efforts by the local speakers of indigenous languages to communicate with the Chinese immigrants for trade and other restricted interactions would have been conducive to the development of a pidginized form of Chinese (for discussion, see Section 3.2). Thus whilst not essential for the classification of a language as a creole, Xining Mandarin can reasonably be assumed to have had a pidgin stage early on in its development (cf. Dede, 2003: 345$)^{2}$

The purpose of this paper is to examine the historic language contact scenario responsible for the emergence of non-Sinitic syntax in Xining Mandarin, including the demographic conditions, and the types of interactions that occurred between the Ming military settlers and the local populations. The primary argument that will be made is that Xining Mandarin represents a case of 'fort creolization' (Bickerton, 1981) or 'gradual' creolization (Byrne and Holm, 1993) similar to that found for certain European lexifier creoles, with syntactic interference arising due to poor access to the Chinese lexifier among the indigenous populations.

2 Before proceeding further, a brief note may be helpful about the issue of 'mixed languages', as there is some conceptual overlap between 'mixed languages' and 'creoles', and the former designation has also been applied to the Chinese lexifier contact varieties of Qinghai-Gansu in some studies. On the typical use of these terms, there are considerations which show that the Qinghai-Gansu varieties can be more legitimately categorised as creoles (on the defintion given above). In particular, whilst both creoles and mixed languages are of non-straightforward genetic heritage (criterion (b) above), a distinction exists between pidgins and creoles which arise due to a communicative need (speakers lack a common language), and mixed languages, which are generally defined as emerging in communities that already speak each others' languages. The purpose of the latter is rather to function as 'in-group identity marker[s]' (Velupillai, 2015: 70, 81) for an 'expressive function', such as maintaining a threatened identity (Meakins, 2013). In the case of Xining Mandarin, there was no shared language; it emerged through contact between colonizers settling among substrate populations who did not speak the language of the colonizers, as in fort creolization scenarios elsewhere (see Section 5). As such, the property of displacement (criterion (c) above) also helps to distinguish creoles from mixed languages (for which displacement is not a defining feature). In addition, mixed languages are generally considered to arise from only two source languages (often with a clear lexical or grammatical contribution from each source language), whereas creoles usually have multiple source languages contributing to their grammar with only the lexifier being clearly identifiable (Meakins, 2013; Velupillai, 2015). With regard to Xining Mandarin, its head-final clausal syntax cannot be traced exclusively to one source language, as it has experienced historic contact influence from multiple head-final substrate languages (of Mongolic, Tibetic, and Turkic provenance). 
The discussion is organized as follows. In the next section, an overview will be provided of the creole features of the dialect, presenting them alongside similar features in the local languages (Section 2). Then, in Section 3, the nature of the Chinese colonization of Qinghai will be explored. Section 4 critiques a previous rapid shift-based account of the origin of Xining Mandarin, Section 5 introduces the gradual/fort creolization analysis, Section 6 considers linguistic mechanisms of change in the dialect, and Section 7 concludes.

\section{$2 \quad$ Creole Features of Xining Mandarin}

The outline in this section begins with the verb phrase, and then moves up the clausal hierarchy to consider auxiliary verbs, tense markers and verba dicendi complementizers. In each case it will be demonstrated that Xining Mandarin has come to possess head-final features which are typological anomalies among Sinitic languages and which contribute to the syntactic convergence of the dialect upon the typology of the local head-final non-Sinitic languages. ${ }^{3}$

\subsection{Word Order}

The Xining dialect's verb-final word order can be seen in the ditransitive construction below, where both objects precede the verb.
(1) Wang laoshi yi ben fu jia ha gei-zhe NAME teacher one CL book $3 \mathrm{SG}$ овJ give-ASP 'Teacher Wang is giving a book to him.' (Bell, 2019)

By contrast, despite allowing object fronting in some circumstances (cf. Section 6), Modern Standard Mandarin is a VO language - like Chinese has been throughout its history (e.g., Paul, 2015).
(2) Xiao Wang gei le ta yi ben shu [Standard Mandarin] NAME give PFV $3 S$ one CL book

'Xiao Wang gave him a book.'

3 The focus of this paper will be on the creole features of the traditional or 'Old Xining dialect'; $20^{\text {th }} / 21^{\text {st }}$ century debasilectalization as a result of contact with Modern Standard Mandarin, and the associated Sinitic patterns, are beyond the scope of this paper (cf. Dede, 1999a, 2003). 
The OV property of Standard Mandarin can be further seen from the fact that various types of object cannot occur in sov constructions. For example, the $3^{\text {rd }}$ person pronoun cannot occur pre-verbally in (3). Similarly, wh-objects may not freely occur preverbally (4).

(3) *Wo-de pengyou ta renshi [Standard Mandarin]
1SG-Poss friend 3SG know
(intended) 'My friends know him.' (Paul, 2002: 700)
(4) Lao Bi ( ${ }^{*}$ shenme $)$ chi-le (shenme) [Standard Mandarin] NAME what eat-PFV what
'What did Lao Bi eat?'

By contrast, Xining Mandarin, which possesses sov as a basic word order (cf. Cheng, 1980; X.-R. Jia, 1990; Yang 2009), allows both of these types of object to occur preverbally as an unmarked order $(5,6)$. The object may be marked with the object marker $h a[\mathrm{xa}]$, which resembles accusative case marking in the local languages (e.g., 7 below) and functions to disambiguate the semantic roles in the sentence (in 5 , it prevents the reading on which the sentence-initial NP is a fronted object - i.e., 5 cannot mean 'He/Lao Bi likes Xiao Wang').
(5) Xiao Wang jia ha/Lao Bi ha xihuan zhe [Xining Mandarin] NAME 3 PL OBJ/NAME OBJ like IPFV
'Xiao Wang likes him/Lao Bi.'
(6) Lao Bi sha ha chi-liu [Xining Mandarin] NAME what OBJ eat-PFV 'What did Lao Bi eat?'

Despite being a non-Sinitic feature, OV basic word order in Xining Mandarin reflects the basic word order in the province's indigenous languages - Mongolic, Tibetan and Turkic varieties. Because the Monguor people (Chinese: Tuzu 土 族) were the primary inhabitants of the river valleys around Xining in the late $14^{\text {th }}$ and $15^{\text {th }}$ century when the contact scenario with Chinese speakers began to take shape (see Section 3), this language outline uses the Mongolic varieties spoken by the Monguor to illustrate the head-final features of the local languages. There are two primary varieties spoken by the Monguor: Mangghuer and Mongghul. Like in Mongolic languages elsewhere, the verb occurs clausefinally, following the object, as illustrated below for Mangghuer in (7). 
(7) Ni muni aguer=ni ala ge-jiang. [Mangghuer (Mongolic)] This $1:$ SG:GEN daughter=ACC kill do-OBJ:PERF 'It killed my daughter.'

(A Cow Mother 36; Z. Chen et al., 2005, cited in Slater, 2003: 164)

\subsection{Auxiliary Verbs}

Furthermore, consistent with the typology of OV languages, auxiliary verbs in Xining Mandarin can be found clause-finally to the right of the verb. Whereas in Standard Mandarin, modals precede the verb (as in 8), the Xining dialect's modal of necessity yao occurs following a nominalizing particle (as in 9).

(8) ni xuyao ba na ge shoushi yixia [Standard Mandarin] 2SG need BA that CL tidy a little

'You still need to tidy that up.'

(9) ni na ge ha haishi shoushi de yao lia [Xining Mandarin] 2SG that CL OBJ still tidy NMLZ must PRT 'You still need to tidy that up.'

As Dede (2016) points out, this is a structural pattern in the dialect, and not simply a discourse irregularity, such as an afterthought expression. The pattern closely reflects that found in Monguor (Mongghul (Mongolic)), which effectively nominalizes the main verb using the future participle $g u$ (Ibid.: see 10). Similarly, the word order Main Verb - Modal Auxiliary is also seen with other modals, such as the modal of possibility chuang in (11), even though Sinitic languages show the word order Auxiliary Verb - Main Verb.

$\begin{array}{llll}\text { (10) Gan luanhan } & \text { rde-gu } & \text { gulagu-na } & \text { [Mongghul] } \\ \text { 3SG a lot } & \text { eat-FUTPTCP } & \text { need-NPST } & \end{array}$

'He needs to eat more.' (Dede, 2016: 559)

(11) nomen xian zou-tuo, lu-shang ba na liang ge [Xining Mandarin] ${ }_{1} \mathrm{PL}$ first walk-start road-on BA that two CL

peng-shang ho chuang

bump-on COND perhaps

'Us two will go first. We might bump into those two on the way.' (S.-C.

Wang, 2012: 473, translation by DB)

The pattern here in the Xining dialect, as Dede (2016) notes, is Main Verb Conditional Marker - Modal Auxiliary. This follows the pattern in Monguor (Mongghul), which also uses the modal following a conditional marker (12). 
Thus for both modals the structure is identical to that in Monguor, both in terms of order (Main verb - Auxiliary) and the use of an intervening particle (nominalizer or conditional marker).

\section{(12) gan xangjoggi
3SG banana-AC
'He will probably}

Moving up the clausal hierarchy, the next area where contact interference is evident is with regard to tense marking. Future marking in Standard Mandarin is primarily accomplished using pre-verbal modal auxiliarys (e.g., hui 'will'; yao 'will, want') and temporal adverbs (e.g., mingtian 'tomorrow'):

\section{(13) Lao Bi mingtian yao qu Beijing [Standard Mandarin] NAME tomorrow will go Beijing \\ 'Lao Bi will go to Beijing tomorrow.'}

However, rather than relying on preverbal modals such as yao 'will, want', Xining Mandarin uses the clause-final particle lia as a future tense marker with non-stative predicates (Bell, 2017). In simple sentences, lia may co-occurr with future adverbs (e.g., $m i \tilde{\partial}^{24} t s 0^{55}$ 'tomorrow' in (14)) but not past adverbs $\left(i^{2213} \varepsilon^{24}\right.$ 'yesterday' in (15)). Meanwhile, when no adverb is present, a future reading is required if lia is used (16).

(14) $t_{6} i a^{24} \quad m i \tilde{a}^{24} t s \jmath^{55} \quad l \varepsilon^{24} \quad$ lia $/ * l i s \quad$ [Xining Mandarin] 3SG tomorrow come lia / $/ \mathrm{PFV}$

'Tomorrow he will come.' (Bell, 2017:69)

(15) t6ia $^{24} \quad i z^{213} l \varepsilon^{24} \quad l \varepsilon^{24} \quad$ lis $\quad / * l i a \quad$ [Xining Mandarin] 3SG yesterday come PFV /lia

'Yesterday he came.' (Bell, 2017:69)

(16) $n 5^{44} \quad i^{z 44} \quad t^{h} i^{44} \quad$ lia $\quad$ [Xining Mandarin] 1SG also listen lia

'I will also listen.' (Bell, 2017: 74)

However, in stative predicates, no future marking function is found, and the particle simply has a modal function, indicating what has been described as indicative mood with strong subjective speaker attitude $(\mathrm{Du}, 1995)$ or găntànyǔ $q i$ 感叹语气 'exclamative mood' (Zhang and Wang, 2012). 
$\begin{array}{lllll}\text { (17) No huimin jiu shi lia } \\ \text { 1SG } & \text { Hui.people really be lia }\end{array}$

'I am Hui.' (A-S. Zhang, 2007: 351, translation by DB)

In terms of the origin of this particle, Monguor (Mongolic) has been suggested as the source language in the literature (e.g., Du, 1995). The examples below illustrate the same aspectually-conditioned future tense marking found in Xining Mandarin with data from Monguor (Mongghul), spoken near Xining.

(18) Bu mudie-m [Mongghul]

1SG know-IPFV

'I know.' (Åkerman, 2012: 28)
(19) Tingera uro-m [Mongghul] sky rain-FUT
'It will rain.' (Åkerman, 2012: 29)

Just as we saw in (14-17), the Monguor examples here show that with the stative verb mudie 'know' there is no future reading, whereas with the activity verb uro 'rain' a future reading is derived (in Section 6, it will be suggested that the temporality of Xining lia is modelled on this Mongolic pattern).

\subsection{SAY Complementizers}

The final creole feature to be considered here comes from the top of the clausal hierarchy, and is a clause-final SAY complementizer which shows significant syntactic differences from such forms in other Chinese dialects (A-S. Zhang, 2007; Bell, 2018). Elsewhere, Sinitic complementizer forms produced via grammaticalization of a speech verb remain part of the matrix verb complex outside of the complement clause, as described in (20), and so can be termed verb particle complementizers (Chappell, 2008; cf. Matisoff, 1991: 398; Bell, 2018):

(20) Emergence of Sinitic particle complementizers (Chappell, 2008: 57)

$\mathrm{NP} \mathrm{V}_{\text {[quotative] }}$ (intonational pause): s["Direct Speech"]

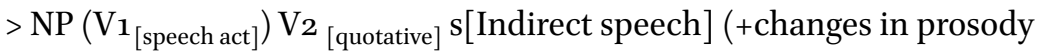
and pronominal deixis)

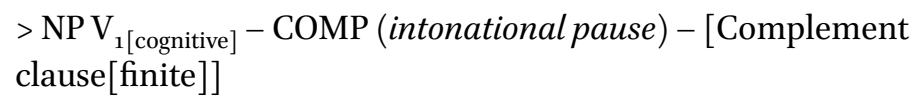


Example (20) indicates that the SAY complementizer develops from a grammaticalized quotative verb in a serial verb construction which comes to be used with cognitive matrix verbs (thus having undergone semantic bleaching). By this point, as Chappell (2008) shows, it has become an 'invariable particle' complementizer which remains attached to the preceding verb; unlike in some languages, it does not undergo constituent reanalysis to become part of the complement clause (rather, as in (20), there is typically an intervening intonational pause). This type of complementizer is illustrated below by the case of Beijing Mandarin shuo in (21) (from the speech verb shuo 'say') which occurs with the cognitive verb lijie 'understand'.

(21) ta yinggai lijie $\quad$ shuo, ni dui ta de [Beijing Mandarin]
3SG should understand shuo, 2SG to 3SG POSS

zhe zhong yueshu shi

this kind restriction be

dui ta de yizhong guanxin

to 3 SG POSS a.kind care

yizhong ai, er bu shi qiangzhixing de cuoshi a.kind love, CONJ NEG be controlling pOss measure

'He should understand, the restrictions you are putting on him are a kind of care, a kind of love, and not controlling measures.' (Fang, 2006: 111 , translation by DB)

Comparing the standard case in other Chinese dialects to Xining Mandarin, the most obvious difference is the location of Xining Mandarin's SAY complementizer fozho, which derives from the dialect's speech verb fo 'say' (IPA: $\left.\left[\mathrm{fj}^{44}\right]\right)$ and the imperfective marker $z h o$. The complementizer can be seen in (22) and (23) attached to the right edge of the complement clause and preceding the matrix speech verbs fo 'say' and han 'shout' (22, 23). As well as occurring with speech verbs, the SAY complementizer can be used with verbs of cognition, such as xiang 'think', indicating that it no longer denotes a speech act (24).

(22) jia no ha jia Beijing qu lia fozho fo-zhe [Xining Mandarin] 3SG 1SG OBL 3 SG Beijing go FUT CMP say-ASP

'He said to me that he will go to Beijing.' (Bell, 2018) 
(23) gou a che-tuo, lang lai li fozho [Xining Mandarin] dog PRT bark-start, wolf come FUT CMP

han lia ko

shout MOD PRT

'The dog started barking. (S/he) was shouting that a wolf is coming.'

(Bell, 2018)

(24) na no ha qu ha hai mai ge fuxi then 1SG TOP go COND still buy CL revision

$\begin{array}{llll}\text { ziliao } & \text { fozho } & \text { xiang-zho } & \text { zho } \\ \text { material } & \text { CMP } & \text { want-IPFV } & \text { PRT }\end{array}$

'I think that if I go, I will still buy revision materials.' (Bell, 2018)

Although unattested among Chinese dialects elsewhere, a head-final sAY complementizer is found among the local substrate languages, notably in Monguor (Mangghuer), and looks very much like a calque of these forms. Just as in the Xining Mandarin examples above, the Manggheur SAY complementizer ge-ji (from the speech verb ge and imperfective -ji, occurs between the complement clause and the sentence-final matrix verb).

(25) tingsa jiutou yaomao $[r-a] \quad$ ge-ji [Mangghuer(Mongolic)]

Later nine.head ghost come-VOL QUOT-IPFV

dayingla-jiang.

promise-OBJ.PFV

'Then Nine-headed Ghost promised, saying "I'll come."'

(Nine-headed Ghost 38; Z. Chen et al., 2005, in Slater, 2003: 287)

Thus, to summarize what we have seen so far, the basic OV word order in the VP, the VP-final position of modal auxiliary verbs, the clause-final position of future tense marking, as well as both the form (SAY + IPFV) and clause-final position of the dialect's SAY complementizer constitute morphosyntactic forms that are anomalous among Chinese dialects, and align the dialect instead with the Mongolic morphosyntax of the indigenous Monguor people. However, beyond noting the obvious similarity with the regional non-Chinese languages, the historical and linguistic puzzle remains concerning how and why such creole features arose in this Chinese dialect. The rest of this paper, 
therefore, explores how Xining Mandarin came to possess such features, in order to shed light upon the language contact scenario that enabled such heavy interference in the regional variety of Mandarin.

\section{3}

\section{A Historical Outline of the Contact Scenario ${ }^{4}$}

By way of background, it must be noted that Xining Mandarin is a member of the 'Qinghai-Gansu Sprachbund' (Slater, 2003) - named after Qinghai province (of which Xining is the capital city) and the neighbouring Gansu province and this designation highlights the structural isomorphism that is evident across the Mongolic, Tibetic, Turkic (and now Sinitic) languages spoken in the wider region. Yet, as Thomason (2001: 104) points out, the underlying social mechanisms responsible for the emergence of convergence phenomena in Sprachbunds can vary greatly, involving factors such as trade, exogamy, language shift by local peoples to the language of invaders, and migration. With regard to Xining Mandarin, the contact scenario with which we are concerned crucially involved the Monguor people, who were the primary and dominant inhabitants of the area around Xining when the Chinese settlers began to arrive in the early Ming period, and thus were termed by the Chinese turen, tumin 'indigenous' (cf. Tuttle, 2006: 40; for details on their location, see below). However, the particular societal dynamics that arose between the Monguor and the Chinese settlers have yet to be adequately addressed from a socio-historical and linguistic perspective.

With regard to why this study begins in the early Ming period (the late $14^{\text {th }}$ and early $15^{\text {th }}$ century), even though archeological finds show that Chinese military colonization of Qinghai dates back as far as the Han to Jin period ( $3^{\text {rd }}$ century BC $-3^{\text {rd }}$ century AD; Tong, 2008), there is considerable evidence that the modern dialect dates back to no earlier than this period (cf. Zhang, 1992; Dede, 2003; Lu, 2011). This evidence centres upon the fact that prior to the Ming, Chinese efforts at colonization (and thus the uptake of the Chinese language in the area) were repeatedly halted by the conquest and occupation of the region by alien powers. It is known that pre-Ming Chinese

4 With regard to the primary sources referred to in this study (which are mostly interpreted through the secondary literature), besides a main source on Ming history, Mingshi 明史, these are the relevant local Ming and Qing dynasty annals, including the Xining Guard Gazetteer (Xining wei zhi 1993 [1595]), the Xining Gazetteer (Xining zhi 1993 [1657]), and the New Gazetteer of Xining Prefecture (Xining fu xin zhi 1988 [c. 1747]). I also draw on Louis Schram's $(2006$ [1954, 1957, 1961]) account, which is based largely on annals of Xining and Gansu (including Xining fu xin zhi (c. 1762) and Gansu xin tong zhi (c. 1909 [1728-1736]) and on what he learned firsthand from living among the Monguor for 10 years during the early part of the twentieth century. 
expansion into northeast Qinghai occurred under the Tang dynasty (618-907), but the Tang presence was subsequently overcome by the Tibetan Tufan empire, bringing northeast Qinghai under Tibetan rule from about the mid $8^{\text {th }}$ century to mid to late $9^{\text {th }}$ century (Cui, Zhang, and Du, 1999: 195-203). Later, Chinese conquests by the Northern Song $(960-1127)$ at the turn of the $12^{\text {th }}$ century returned the region to Chinese central control (Ibid.: 240). But only about 30 years later, in 1131, the Jurchen Jin 金 (a Tungusic people from Manchuria), having succeeded in overcoming the Northern Song empire elsewhere in China, proceeded to occupy eastern Qinghai. This ushered in a long period in which Qinghai was controlled by successive alien powers, the most notable of which began when Genghis Khan overcame the Tangut or Xixia 西夏 forces in Xining in 1227, introducing Mongol rule under the Yuan 元 dynasty (1206-1368). The Monguor people who occupied the river valleys around Xining in the early Ming were descended, at least in part, from Genghis Khan's Mongols, with the late $14^{\text {th }}$ century Monguor prince of the Qi clan (who lived to the south of Xining) a seventh generation descendant of Genghis (Tuttle, 2006: 40).

It can therefore safely be assumed that, following each ousting of the preMing Chinese military presence, Chinese survivors who did not flee the area would sooner or later have been assimilated into the non-Chinese populations of these dominant alien powers (in line with e.g., Schram, 2006 [1954]: 110-12, 125; Dede, 2003; Lu, 2011). Accordingly, when the Ming dynasty Chinese armies arrived in what is now northeastern Qinghai province in the early 1370s, rather than finding Chinese colonies, they thus encountered the indigenous non-Chinese peoples. ${ }^{5}$

\subsection{Chinese Fortifications and the Socio-geography of Qinghai-Gansu}

In terms of how the contact scenario unfolded, at the outset of the Ming period, the Ming Emperor, Zhu Yuanzhang 朱元璋 (r. 1368-98), implemented a nationwide reorganization of the military system, organizing it into a guard and battalion (weisuo 卫所) system. Xining Guard (wei 卫) was established on February $9^{\text {th }} 1373$ and initially comprised five battalions (qianhusuo 千户所)

5 For reasons of space I will not discuss other reasons for assuming an early Ming origin for the dialect, but only mention that another important source of evidence is the jiapu 家谱 'family genealogies' and beiji 碑记 'tablet inscriptions' of those Han Chinese who identify themselves as natives of Qinghai (as opposed to modern immigrants) (e.g., C.-C. Zhang, 1992: 72). These documents record that their ancestors came to the area during the early Ming period. 
stationed at Xining (weicheng 卫城) and in the surrounding area (cf. Cui, 2016). In view of what is known about the organization of the guard and battalion system, each battalion would as a rule have contained 1120 soldiers, divided into 10 Companies (baihu 百户).

The Chinese colony established in Xining Guard marked one of the westernmost points of the northern Ming frontier. The area under the direct jurisdiction of Xining Guard during the Ming reached from Xishi gorge (Xishi xia 西 石峡) in the west (at the border of modern Huangyuan and Huangzhong county), to Datong in the north, to the Laji mountains in the immediate south, and in the east/northeast it reached to the border of Zhuanglang 庄浪 Guard (in modern Yongdeng county, Gansu province), and included Ledu and Minhe which can be seen by the lower reaches of the Huangshui river on the map below (cf. Cui, 1988).

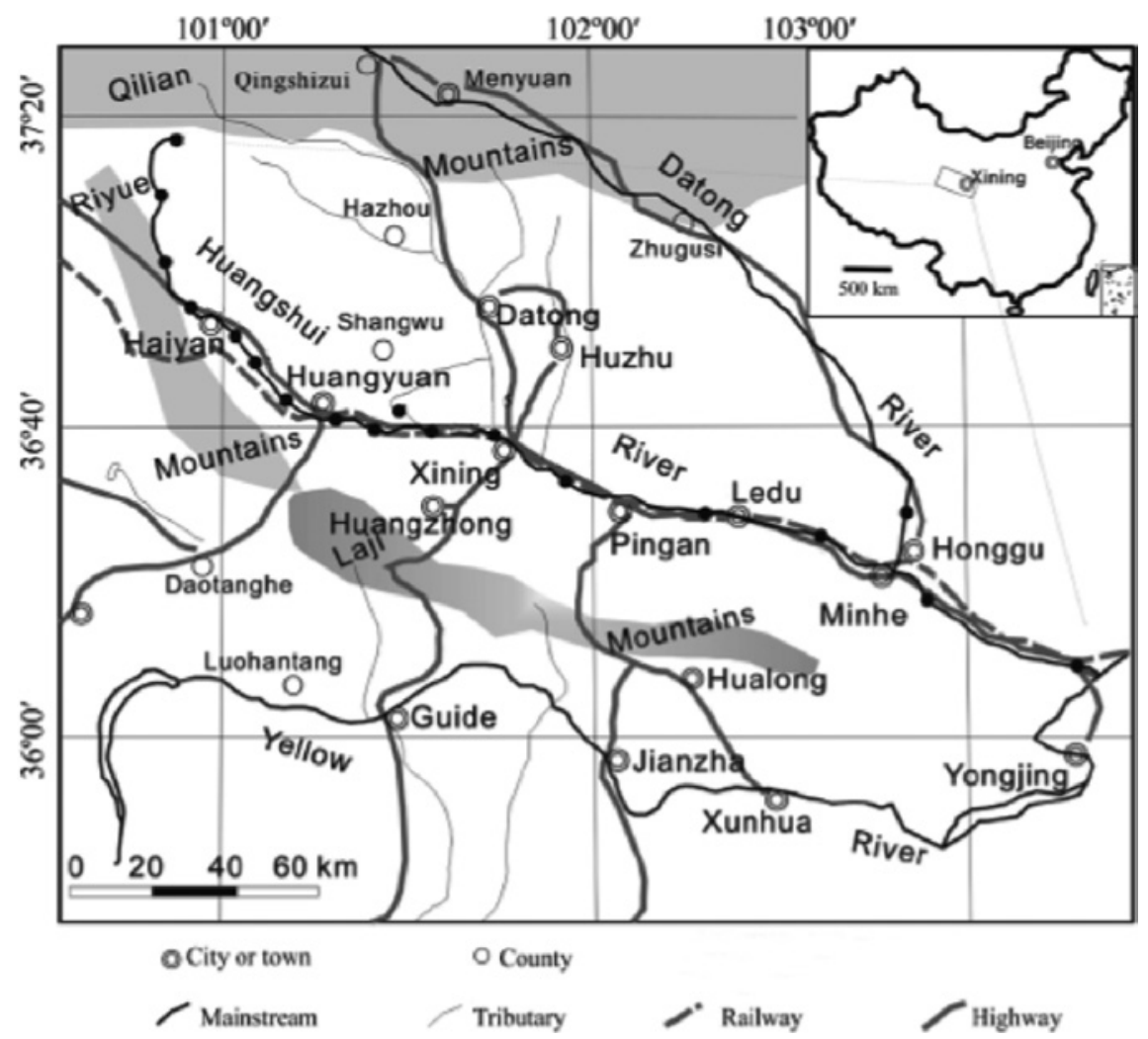

FIGURE 1 Map of the modern Huangshui river basin (adapted from Tan et al., 2012: 157) 
At the grassroots level, besides the battalion fortifications, the Chinese colonialization strategy involved the establishment of many small agricultural fort colonies (baozhai 堡寨), particularly in the flat and fertile valley areas along both sides of the Huangshui river (Chen, 1996; Jia, 2012: 35). Each fort was manned by a company (baihu 百户), which, as a rule, comprised 112 soldiers, dispatched from the regional battalions. In accordance with the state farm policy (tuntian 屯田), these soldiers in the forts cultivated the land and grew grain, making the colonies self-sustaining. During the Ming period (i.e., over two and half centuries from 1368-1644), over 200 such forts were constructed in the Huangshui river basin (cf. Chen, 1996; Jia, 2012: 37).

In terms of the number of Chinese settlers in the area, which has implications for the amount of access to Chinese available to the indigenous population, it is apparent from the official Ming figures that the demographic situation was one in which the Chinese colonists were severely outnumbered by the autochthonous ethnic groups. Table 1 shows the Chinese population figures for the Ming given in the New Gazetteer of Xining Prefecture (c. 1747).

TABLE 1 Population figures for Xining Guard from the New Gazetteer of Xining Prefecture (Xining fuxin zhi 西宁府新志, cited from Li, 2010: 70)

Period

1368-1398 (reign of the Hongwu emperor)

1402-1424 (reign of the Yongle emperor)

$15^{21-1567}$ (reign of the Jiajing emperor)

$1578\left(6^{\text {th }}\right.$ year of reign of the Wanli emperor, 1572-1620)
Population in Xining Guard

7200 families of officials and military colonists (guanjun hu 官军户); 15854 individuals 7200 families of officials and military colonists (guanjun hu 官军户); 12092 individuals

3578 families of officials and military colonists (guanjun hu 官军户); 45613 individuals 256o families ( $h u$ 户); 440 civilian families (baixing $h u$ 百姓户), 38892 individuals

With regard to what this data tells us about the Ming period overall, Louis Schram (2006 [1954]: 282) observes that by the late Ming (the Wanli period referred to in Table 1) the number of military families was reduced by two thirds from what it was in the early period, and there were only a small number of civilian settlers present. He helpfully summarizes as follows: 
Until 1723 this region, called Huang Chung [Huangzhong $]$, had been unsuccessfully colonized several times by Chinese settlers as an adjunct to Chinese garrisons. These attempts had failed because of [Mongol and Tibetan] tribal wars and frontier inroads. The population had remained thin, and its components had frequently changed and moved. The Ming dynasty, beginning in 1368, had settled Chinese colonies and posted Chinese garrisons in only a few localities, controlling the rest of the region by accepting the allegiance of the Monguors under their various T'u-ssu [tribal chieftains].

In other words, the historical records show that although the Ming colonists never lost their military hold of the area along the Huangshui river on which Xining is located, they were not able to ensure the safety and security of the area to a sufficient degree, especially in the mid to late Ming, to allow Chinese civilian society to flourish. ${ }^{7}$

Meanwhile, with regard to the indigenous peoples, in response to the imperial edict of the Ming emperor Zhu Yuanzhang, the Monguor (and Tibetan) clans in the area formally surrendered. In return for their allegiance, Chinese military titles (e.g., battalion commander (qianhu千户), company commander (baihu 百户)) were bestowed upon the tribal chieftains (Gong, 1992: 1320ff.), giving them (partly honorary) roles within the Ming military organization. ${ }^{8}$ Through this native chieftain system, which was used across the Chinese frontier, the border peoples were loosely accommodated into the administrative system of the Chinese state, removing the need for military confrontation. After being incorporated as protectorates, the aboriginal clan leaders retained sovereignty in the civil governance of their clans, with their role primarily

6 That is, the area between the Datong river, Xining (or Huangshui) river, and the Yellow river (Schram, 2006 [1954]: 110).

7 However, colonialization did not ultimately fail in the sense that even during the mid to late Ming as tribal raids became more and more frequent, Chinese power was never fully overcome (unlike during pre-Yuan colonization, when the Chinese military presence was overcome by alien powers). The records show that the situation changed somewhat during the following Qing period (1644 to 1911). During the Qing, despite large fluctuations, Chinese immigration continued and on a much larger scale than during the Ming period, with the Chinese gradually gaining a stronger and stronger hold in the region: 1645 (13686), 1746 (70470), $1853(328,520), 1909$ (153,595) (figures for Xining prefecture, also from the New Gazetteer of Xining Prefecture; Li, 2010: 70).

8 These native chieftains were known as tusi (土司) or tuguan (土管), which according to Serruys (1955: 257, note 146) were not titles in themselves but general terms denoting the native chieftains. These native chieftains were unsalaried (Serruys, 1955: 264), indicating that their Chinese titles were somewhat nominal. 
military, centered upon calling up soldiers from within their territory to defend the frontier from attack by hostile tribes.

In terms of their geographical distribution, the populous Monguor in the Huangshui river basin were relegated to outlying territories positioned so as to guard the passes of valleys by which the Chinese colonies could be attacked. As Schram (2006 [1954]: 155) notes, "[w] hile the Monguors were thus allocated to the valleys leading up to the frontier passes, the Chinese planted colonies of their own people in the vicinity of the main towns."

The Monguor were consigned to land that was poorly irrigated in comparison to that occupied by the Chinese colonies, and so not as good for farming (Schram, 2006 [1954]:129-130). The distances involved between Xining and the Monguor clans varied by clan: the Qi clan, for example, was located 35 miles south of Xining, the Li clan 10 miles south of Xining and the Ch'eng clan 17 miles to the north, and the Na clan the closest at 3 miles south of Xining (Schram, 2006 [1954]: 127; Ibid.: 4 for a map). Aside from the Monguor clans, the local Tibetan tribes (sometimes known in Ming sources as the 13 tribes of Huangzhong) likewise surrendered (cf. Luo and Gao, 2006: 67). According to Jia (2012: 67), these were spread across the large area from the east of Laji mountain, north of the Yellow river, and south of the lower reaches of the Datong river. What thus arose across the region was something of a patchwork of Chinese settlements and self-governing Mongour and Tibetan protectorates; sometimes the latter were surrounded by Chinese forts, whilst in other cases they remained more isolated, depending on their location (cf. Serruys, 1955: 259; Dardess, 2003: 122).

As for the size of the indigenous population, Jia (2012) estimates that there was a population of about 150,00o under the jurisdiction of the local tribal chieftains by the late Ming and early Qing, which was substantially comprised of Monguor. ${ }^{9}$ Meanwhile, the Tibetan population in Xining Guard increased significantly throughout the Ming, and during the Wanli period (1572-1620) exceeded 80,000 (based on figures, e.g., in the New Xining Gazeteer, W. Jia, 2012: 67-9; cf. W.Jia, 2001: 75). What is clear from the available population data is that the Chinese settlers were not only severely outnumbered in the early Ming when they began to arrive, but that numerical parity was not reached for the Chinese and the resident non-Chinese populations throughout the duration of the Ming.

As well as outnumbering the Chinese settlers, social factors existed which contributed to the local population retaining significant independence from

9 In terms of the map in Figure 1, Jia (2012) refers to the Hehuang region, which denotes an area centred around the Huangshui river basin: the area north of the Yellow river, east of Laji mountain, south of the Qilian mountain range, and also includes the area around where the Huangshui river enters the Yellow river. 
the colonizers. In particular, it was a tenet of the Mongolic culture (cf. Serruys, 1980: 91-2), enforced by the Chinese-instituted native chieftain (Tusi) system, that the ordinary Monguor could not wander off and leave their tribal leader to settle in Chinese territory. According to Schram (2006 [1954]: 172), "[t]his conviction of being chained [to their lord] was deeply rooted in the social consciousness of the Monguors and was considered by them to be natural" (Ibid.: 171). The individual Monguor had the freedom of movement within the limited territory of the native chieftain, but if he [the individual Monguor] tried to leave his village and settle in Chinese territory, the Chinese officials would return him to the jurisdiction of his hereditary T'u-ssu (Ibid.: 274). That is, the Chinese officials upheld the authority of the native chieftain as the 'owner' of the common Monguor in his clan, and from an administrative perspective, the chiefs continued to govern their clans according to their traditional Monguor customs, without interference from Chinese officials from the fort colonies (cf. Schram, 2006 [1954]: 156). In other words, Ming immigration did not as a rule result in mixed communities (i.e., villages) of Monguor/Mongolians and Chinese living together (cf. Serruys, 1955: 299).

To summarize, therefore, the picture that emerges of the contact scenario in the Xining area in the early Ming period is of the local non-Chinese speaking Monguor clans facing the arrival of Chinese soldiers and colonialists, whom they greatly outnumbered, and with whom they had only a limited degree of social integration. Accordingly, interactions between the indigenous tribes and the Chinese settlers can only have been sporadic for much of the local population, especially in the early years, but would naturally have become more frequent as the number of Chinese settlers increased gradually throughout the Ming period. In the following sections, we will consider the types of interaction that occurred, focusing on trade and intermarriage, with the former seen to be of greater importance in the Xining area.

\subsection{A Trade Jargon/Pidgin}

Economic motivation to learn Chinese would have been strong among the local tribes, as it enabled profits to be made through trade with the politically dominant Ming dynasty. There is evidence of abundant interracial trade in the Ming period - a prominent example of which was the local clans' exchange of horses for tea (as well as other products of the agrarian Chinese people, like grain, salt and clothing). ${ }^{10}$ The Ming Chinese were in urgent need of horses for military use, since - lacking adequate pasturelands and expertise in horse

10 Rossabi (1998: 255) explains, "tea remained fresh longer than other beverages, was freer of impurities than cold water, and acted as a mild stimulant after prolonged exposure to the cold". 
breeding - their own horses were few and of poor quality (cf. Twitchett and Grimm, 1988: 318). In 1397, Xining was established by the Ming government as a major centre in the region for the tea-and-horse trade (Chen, 1997: 319), because many horses supplied to the Chinese came from the grasslands of what is modern Qinghai province. However, because the private sale of tea to the local tribes harmed the supply of horses to the Ming court, tea production officially became a state monopoly, with the Ming government attempting to restrict the sale of tea to occasional horse fairs conducted on a massive scale (cf. Twitchett and Grimm, 1988: 318). If this state monopoly had been successfully implemented, this strictly regulated trade would probably not have involved much of the local population, and thus perhaps have been of minimal importance as a means of language contact.

However, the fact that the government needed to introduce strict regulations and also monitor their borders continually to prevent tea from being smuggled in (cf. Rossabi, 1998: 256) shows that private trading was an ongoing problem. Independent Chinese merchants arrived in the area in large numbers in order to trade at the markets, to the extent that government restrictions were implemented on the amount of tea that they could bring into the area (cf. Wei, 2011: 58). Twitchett and Grimm (1988: 319) note that from 1470 the tea trade was increasingly conducted by private merchants, and that by 1500 about 60 percent of the trade was illicit, being conducted privately. In any case, the overall political and social effect of the tea-and-horse trade was to create economic dependency and solidify the subjugation of the local clans (the substrate populations) to the Chinese Ming dynasty (Chen, 1997: 324).

In addition, there is evidence of regular officially authorized trade by Chinese soldiers in the wider region. According to Dede (1993: 43), the commander of the neighbouring Hezhou Guard, Ning Zheng (甯正, d. 1396), implemented a policy of supplying soldiers with tea and cloth which they could trade with the locals for food and other daily necessities. Finally, among other commodities, Schram (2006 [1954]: 248) notes that the Monguor sold their grain at markets, purchasing farming tools from Chinese smiths. The fact that Chinese was the language with greater prestige (the local tribes having surrendered and pledged allegiance to the Ming emperor) would naturally have encouraged the use of at least a rudimentary trade jargon or pidgin Chinese (rather than the language of the politically subordinate Monguor) during such marketplace interactions.

\subsection{Intermarriage}

Next, we must consider the role of intermarriage, because interethnic marriage is a conceivable means by which nativization/creolization could occur in 
the early to mid-Ming period, as well as later, as the progeny of these marriages could have acquired a pidgin Chinese as a native language (cf. Dede, 2003: 345). However, there are reasons to believe that interethnic marriage was not a prevalent social phenomenon in the region, and that it played a smaller role than in similar colonialization scenarios elsewhere (see Section 5 below).

Besides the inhibiting lack of social integration between the Monguor and the Chinese settlers already described above, it is significant that in the Chinese colonization of Qinghai-Gansu, Chinese soldiers and officers brought wives and family with them from their home region, a social factor which would surely have made the need for aboriginal spouses less pressing. Indeed, in general, officers tended to marry within officer families, at least for several generations after immigrating to the frontier (e.g., Robinson, 2017: 312). Meanwhile, quite early on in the Ming period - in 1436 - it actually became a matter of policy for soldiers to be encouraged to marry and travel to the frontier with their wives, and it remained so throughout the duration of the Ming dynasty (Szonyi, 2017: 44-5; Yan, 2012). Despite the logistical challenges that this presented, the practice was considered beneficial as a means of reducing the desertion rate in the garrisons (Ibid.). Accordingly, with regard to the numbers involved, J.-K. Zhang (2007: 54) states that, in general, it is undeniable that numerous family members accompanied soldiers to the Weisuo [military garrisons] (cited in Yan, 2012; cf. Jia, 2012: 40). Concerning Qinghai-Gansu in particular, Yan (2012:39), citing an example from the annals for Lanzhou prefecture, concludes that 'on the whole' (dadu 大都) non-local soldiers brought their wives with them when they came to the region. Therefore, whilst some soldiers may have married local women in the early years, and whilst the practice would undoubtedly have contributed to substrate interference in the dialect as interracial interactions increased during the Ming and Qing period, it seems reasonable to regard intermarriage as something of a subplot compared to the broader phenomenon of the gradual adoption of Chinese among the indigenous tribes for the purposes of less intimate social interactions, such as trade (discussed above).

\section{$4 \quad$ Ming Creolization was Gradual Rather than Abrupt}

Today, bilingualism in their native mother tongue and in the Xining Mandarin dialect is prevalent among the Monguor people (e.g., cf. Slater, 2003; Limusishiden and Dede, 2012), and we saw evidence in Section 2 of their Mongolic morpohsyntax across the clausal hierarchy of Xining Mandarin. In Section 3, we saw something of the geography and demographics of the frontier region in 
which the Xining dialect emerged in the early Ming period, as well as some of the interracial interactions that occurred. However, it now remains to consider the actual mechanism by which these non-Sinitic features became part of the regional Chinese language.

In this section we will consider, and argue against, the primary explanation advanced in the existing literature concerning the mechanism of change: language shift. It has been hypothesized that the dialect's creole features arose through shift without normal transmission, in the sense of Thomason and Kaufman (1988), by speakers of the local non-Sinitic languages - and in particular by the Monguor people (Dede, 1999a, 1999b, 2003: 345; Wang and Dede, 2016). Thus Dede (1999a: 9, 1999b: 59-6o, 156) has suggested that the contact scenario arose when substantial populations of substrate speakers across the region abandoned their local languages and shifted to Chinese, and were absorbed into the Chinese society. Similarly, Wang and Dede (2016: 426) write:

In the language shift posited for the Xīníng dialect, a population that was originally non-Chinese-speaking shifted to speaking Chinese (the target language), and in the process carried typological features of their original language into the target language. The shifting population must have had reasonably good access to the target language and been large enough to change the target markedly.

Wang and Dede (2016: 426) suggest that the shift could have occurred within a generation or two (e.g., with the grandparents monolingual in their native language, and the grandchildren mostly monolingual in Chinese), such that there was only a short transitional period of community-wide bilingualism in between.

This proposal of wholesale language shift of non-Chinese speaking communities, such as the Monguor, to Chinese in the early Ming was based chiefly on the nature of the creole features of the Xining dialect (Dede, 1999a; Wang and Dede, 2016; cf. Dede, 2003: 345). As Thomason (2001: 76) notes, language change induced by shift is typically characterized by strong morphosyntactic and phonological interference, with moderate lexical interference. Since strong morphosyntactic interference with comparatively little lexical interference is what we find in the Xining dialect (cf. Section 2), these studies have suggested a shift scenario as the origin of substrate interference. Meanwhile, with regard to the comparative lack of phonological and lexical interference in the Xining dialect, Wang and Dede $(2016: 426)$ suggest that lexical and phonological interference would have disappeared following shift due to the subsequent long-term contact with Chinese. 
However, in view of the discussion in Section 3, it is argued that there are strong socio-historical reasons to doubt the hypothesis that something as spectacular as radical creolization and absorption into the Chinese speech community accounts for how Xining Mandarin emerged. First of all, it is important to note that the heavy structural interference found in Xining Mandarin can be reasonably explained a priori without wholesale language shift being involved, and so the linguistic data alone are insufficient to support a shift account. As Thomason (2001: 74) notes, "the linguistic predictions [i.e., that interference is chiefly morphosyntactic and phonological rather than lexical] are the same for all instances of imperfect group learning of a TL, regardless of whether or not actual shift has occurred". As such, an example Thomason (2001: 76) mentions of shift-induced interference is a variety of Qinghai Mandarin spoken by the Salar, who today remain bilingual in their dialect of Mandarin and Salar (Oghuz Turkic). We thus need to turn to socio-historical considerations in order to decide whether shift or simply imperfect L2 acquisition is a more plausible origin of the dialect's contact features.

With regard to the speed of shift proposed in these accounts, to the extent that it occurred at all, in Xining Mandarin this is more likely to have been gradual than abrupt, because the dialect formed in an endogeneous rather than exogeneous context (cf. Chaudenson, 1977: 264), where there was plentiful access to speakers of the local substrate languages. As Mufwene (2016:359) notes, rapid shift is associated with the combination of two factors: a lack of access to one's native language, and abundant access to the target language through integration or population-mixing with the - usually - economically and politically dominant population (whose language is the target of shift). Thus if speakers are separated from a community of speakers of their native language, shift naturally proceeds faster, but in endogenous settings, where creolization occurs among a concentrated substrate population, shift tends to be much more gradual. We have already seen in Section 3 that the Monguor retained their integrity as social groups, making wholesale shift implausible, but it is also illuminating to consider the non-Chinese population in the QinghaiGansu region in relation to language shift as it occurred elsewhere in China during the Ming period.

Unlike the non-Chinese populations in Qinghai, in the centuries following the collapse of the Mongol Yuan dynasty (1271-1368), the Mongol communities in the Chinese interior eventually disappeared, being absorbed into the Chinese population. Serruys (1980, especially Chapter 8 ) demonstrates on the basis of the reign annals of the Ming emperors (the Ming shilu 明实录) and other sources that the sinicization of the Mongols which remained in China (those that did not flee to Outer Mongolia), found in varying numbers in all of 
the Chinese provinces, was a decidedly gradual affair (cf. also Robinson, 2004). For example, as late as 1491, the president of the Board of Justice, He Qiao Xin 何喬新, requested that the Emperor prohibit the use of the Mongolian language, and noted in his biography concerning Beijing: "the barbarians [which Serruys interprets as Mongols] were wont to wear barbarian clothes and to speak the barbarian language, which ought to be forbidden" (translation by Serruys, 1980: 131; cf. Wei 2018: 168). Thus, the Mongol language and customs survived in the Chinese interior long after the establishment of the Ming dynasty in 1368, and did not disappear early on during the reign of the Hongwu or Yongle emperor (1368-1398 and 1402-1424 respectively). Ethnic absorption and language shift were gradual because, despite having access to Chinese speakers, Mongol speakers were not so thinly scattered among the Chinese as to be without access to communities of mother tongue speakers. ${ }^{11}$ Given that sinicization and language shift was gradual in the Chinese interior, where Chinese power and the ratio of Chinese to non-Chinese was much greater, it can only have been a much slower rather than faster process in Qinghai, where the non-Han population was larger than in the interior provinces and the Chinese exerted less influence over the day-to-day life of the local peoples (cf. Serruys, 1955). ${ }^{12}$

Moreover, unlike the scenario just described for the interior of the country, today ethno-linguistic continuity is evident in Qinghai in the fact that the indigenous communities who speak the Xining dialect still also largely speak their native languages, and, as shown by the genealogical records of the native chieftains, ethnic continuity is evident from the $14^{\text {th }} / 15^{\text {th }}$ century indigenous population to those in the region today (e.g., see Schram, 2006 [1961] for a history of the Monguor Lu clan). That is, in the shift account above, "the [shifting] language community ceases to exist and becomes part of the community of the other language" (Dede, 1999b: 59-6o), but in Qinghai the indigenous communities concerned (notably, the Monguor) continue to exist as ethnolinguistic groups.

\footnotetext{
11 Substantial numbers of Mongols were garrisoned, for example, around the capital throughout the Ming period (Robinson, 2004), and in general the Mongol soldiers formed separate military units from the rest of the army (Serruys, 1980).

12 Thus Serruys (1955: 341) concludes concerning the speed of sinicisation: "[w]ith regard to the process itself of integration and assimilation, one thing stands out, namely that the Mongols of Kansu [an area which incorporated the Huangshui river basin in northeast Qinghai] are mentioned so often and for such a long period [in the Mingshilu 明史录], that we must reach the conclusion that this process of assimilation was much slower than in any other province of China".
} 
To summarize, therefore, because Xining Mandarin represents a case of endogenous rather than exogenous creolization (in which the indigenous populations retained plentiful access to fellow speakers of the indigenous languages), radical creolization (characterized as it is by language shift to the lexifier language) lacks plausibility as the explanation of the origin of the creole features in Xining Mandarin. Rather, given the absence of socio-historical conditions that would compel the Monguor to abandon their mother tongue during the Ming, interference through imperfect group second language acquisition which Thomason (2001: 74) notes also leads to heavy morphosyntactic influence on the target language - surely has greater plausibility as an explanation of the dialect's substrate features. Accordingly, in the next section, we shall argue that the Xining dialect may be considered to be a Chinese-lexifier 'fort creole' (a case of gradual creolization), emerging in socio-historical conditions that closely resemble more familiar cases of European fort creolization.

It is known that there is considerable variation in the socio-historical circumstances surrounding creolization, leading to the possibility of distinguishing between types of creole, as Bickerton (1988) does when he identifies 'plantation creoles', 'fort creoles' and 'maroon creoles'. In terms of Mühlhäusler's (1980: 32) diagram concerning three ways in which creoles may emerge (cf. also Hall, 1962), fort creoles (termed 'gradual creoles' by Byrne and Holm, 1993) such as West African Pidgin English (Guinea Coast Creole English) belong to type 3 . In this case, there is a development from pidgin to expanded pidgin, which is then nativized (cf. Adone, 1994: $5^{-6}$ ).

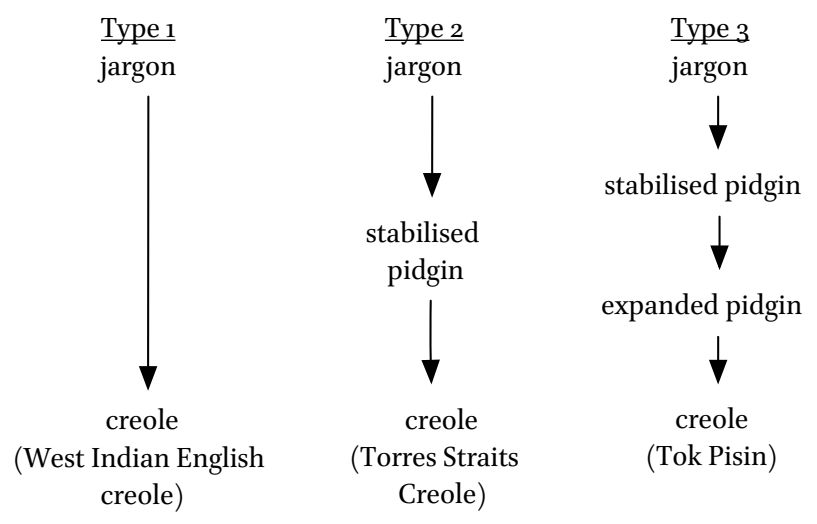

FIGURE 2 Pathways of creole emergence 
Type 1 creolization refers to radical creoles, which form abruptly, for example because the shifting community (typically, slaves from various backgrounds) do not share a common native language and so are forced, for lack of another medium of communication, to rely upon a rudimentary jargon (lexified by the European superstrate). This type of creolization is considered to take a generation or two, with the timeframe involved being between a few years and 25 years or so (e.g., Thomason, 2001: 177). As Walczyński (2012: 93) notes, this pathway is rather rare; examples are usually taken from among the plantation creoles (e.g., Mauritian Creole and Hawaiian creole), though some plantation creoles have been argued to have formed more gradually than was originally thought (cf. Arends, 1993; 1995). In such catastrophic creolization, nativization of the creole would (proto)typically be accompanied by loss of speakers' ancestral mother tongue (i.e., language shift). The claim for type 1 creolization is that there was no opportunity for a stable pidgin stage (i.e., a non-expanded, reduced contact variety adequate only for restricted social functions) because the pidgin was required to immediately fulfil the full range of communicative functions. This type 1 trajectory is essentially what is posited by the account critiqued above in Section 4, which suggested that native Monguor speakers could become monolingual Chinese speakers within 1-2 generations i.e., through 'shift without normal transmission' (cf. Dede, 1999b). However, considering how creoles have emerged elsewhere, it is clear that abrupt creolization is not the normal pattern for endogenous creolisation (see below), which makes the type 1 trajectory implausible for the Xining dialect. In type 1 (and 2) creolization, where it is a jargon/pidgin that is nativized, grammatical expansion occurs through children rather than continued adult language acquisition.

At the other end of this continuum are type 3 creoles, which form much more slowly (with the mother tongue continuing in use alongside the pidgin). Thus, as Mufwene (2008: 76) notes, children were not instrumental in the development of Tok Pisin (an English lexifier creole of Papua New Guinea) or Nigerian Pidgin English into expanded pidgins. Rather, grammatical expansion, and extension into all social domains, was accomplished during the course of adult second language acquisition over several generations before nativization/creolization occurred..$^{13}$ In line with their endogenous nature and the continuing access to the local culture and languages, the outcome of fort creoles is mostly bilingualism or multilingualism (rather than language shift) (e.g., as in Guinea-Bissau Kriyol, cf. Velupillai, 2015: 51-2). In terms of linguistic

13 On Tok Pisin, see e.g., Sankoff and Laberge, 1973; Mühlhäusler, 1980; on Nigerian pidgin English, cf. Shnukal and Marches, 1983). 
outcomes, as noted by Bryne and Holm (1993: $5^{-6)}$, the sustained historic bilingualism associated with 'fort' or 'gradual' creoles results in far-reaching and pervasive influence from the substrate languages upon the creole - an observation that reflects the bilingualism characterizing the Monguor around Xining and the plethora of syntactic features in which the Xining dialect resembles its Mongolic substrate.

Fort creoles emerged, among other places, in Upper Guinea, at the forts from which the Europeans conducted their trade operations (Arends, 1994: 16). In terms of the socio-political situation in such settings, the colonizers' direct control and influence over the local population tended not to extend much beyond the forts themselves, reaching at most to the adjoining villages (e.g., cf. Huber, 1999: 11). That is, as Bickerton (1988: 269) notes, there were various other classes of local people who depended economically on the fort community, and who also used the emerging contact variety, such as servants, contract laborers, and merchants, but these constituted a fringe of interaction which faded into the local population at large as distances increased from the fort. For this reason, there was plenty of opportunity for dilution of such contact varieties among those for whom access to the target was poor.

Similarly, in the Xining area, as we saw in Section 3, the Monguor tribes retained a high degree of autonomy from the Chinese fort colonies, living in their own areas of land, and governed by their native chieftains rather than by direct Chinese rule. As such, access to Chinese would have been poor for much of the Monguor population (e.g., coming about through deliberate excursions into Chinese territory, or through meeting traders at market places). However, the occurrence of such market-based communication and other sporadic interactions would naturally have required the Monguor to attain at least a rudimentary trade jargon or pidginized Chinese. But as in fort creole scenarios elsewhere, there would have been no reason for this variety to be widely nativised among the Monguor tribes early on in the contact scenario, when interactions with the Chinese were few and for restricted social purposes such as trade. However, the indigenous peoples are today bilingual in the Xining dialect and their local languages, and so evidently a process of nativisation occurred over the subsequent centuries, likely accelerating as Chinese immigration into the area increased and interethnic interactions became more frequent (cf. the immigration figures in footnote 7 above).

Finally, aside from their endogeneous nature and their origin in trade jargon, European fort creoles also emerged in part through mixed marriages between the European men and the local women, resulting in children who acquired as a first language the medium of communication of their parents. However, it is noteworthy that interethnic marriage seems to have played a less significant 
role in fort creolization in the Xining area than in West African fort creoles on the Guinea Coast. Concerning the Guinea Coast, according to Hancock (1986: 90), the European colonizers were all males aged $15-30$, i.e., the sailors did not bring wives with them on the boats. Thus it is unsurprising that the creole formed in part through mixed marriages between these male settlers and native females (before being diluted and altered further through being learned by the wider local population).

However, as we saw above, in Ming China there was a policy of travelling to the frontier with one's family, which together with other cultural factors would have inhibited the role of interethnic marriage in Chinese fort creolization. Accordingly, rather than the prevalence of intermarriage (and early nativization/ creolization by the offspring of such marriages), the primary dynamic in the Xining area would have been the imperfect acquisition of Chinese by the indigenous Monguor tribes for the purpose of trade and other interactions, gradually leading to the scenario observed in the province today: bilingualism in Monguor and the (Mongolized) Xining Mandarin dialect. As a case of endogenous fort creolization, it is argued that this is best conceived of not as abrupt wholesale language shift but rather in line with the gradualist model of creolization (e.g., Arends, 1993; Arends and Bruyn, 1994) reported for fort creoles elsewhere, in which the contact variety develops steadily over multiple generations.

\section{Linguistic Mechanisms of Change}

Turning now to the particular creole features found in the Xining dialect, it is easy to see how sov word order could be adopted by the local non-Chinese speakers during imperfect unschooled language acquisition, especially since the target Mandarin lexifier sometimes made use of object preposing structures anyway. As Wadley (1987) shows, although Mandarin basic word order was capitalize svo in the Ming period, object preposing was more widely evident then than in later periods. Wadley (1987: 114) presents the following example of preposing from the $14^{\text {th }} / 15^{\text {th }}$ century redaction of Laoqida, a language textbook for spoken Chinese, where an $18^{\text {th }}$ century redaction does not use preposing, and which would not usually be preposed in Modern Standard Mandarin.

(26) Zenme Han'er yanyu shuodehao $\left[14^{\text {th }} / 15^{\text {th }}\right.$ century Mandarin] How Chinese language speak.well 'How can you speak Chinese so well?' (Laoqida, Wadley, 1987: 114, my gloss - DB) 
(27) zenme neng shuo women de guanhua? [1 $18^{\text {th }}$ century Mandarin] How can speak 1PL poss Mandarin

'How can you speak our Mandarin?' (Chongkan Laoqida, Wadley, 1987: 114, my gloss - DB)

Given the presence of OV in the substrate, the use of OV in the Chinese superstrate would thus only have encouraged imperfect acquisition, whereby OV emerged as basic word order in the Chinese of the indigenous peoples. ${ }^{14}$

As for modal auxiliaries, like Modern Standard Mandarin, the Ming dynasty Mandarin target language did not make use of clause-final auxiliaries, and so their emergence in Xining Mandarin is a striking case of syntactic interference that could only have occurred because access to the target language was poor enough to facilitate such substantial reordering. We saw one clause-final modal above which looks like a wholesale borrowing (Xining Mandarin chuang, resembling Monguor chuang), with the Monguor people apparently simply importing the auxiliary wholesale from their first language (also indicative of poor access to the target). ${ }^{15}$ Other modal verbs, however, came from the lexifier, such as Mandarin yao 'will, want' (in (28), IPA: $\left[j o^{4}\right]$ ), but have been incorporated into the substrate syntactic pattern by being used post-VP.

\section{(28) $n^{3} i^{3} \quad t s e^{4} \quad x o^{3} x o^{3} t s j \quad 6 y o^{2}$ tsj jo ${ }^{4}$ lja [Xining Mandarin] \\ 2SG then properly study NOM must PRT \\ 'You, then, have to study well.' (Dede, 2016: 555)}

In order for the development of this head-final order to occur for the modal yao, the Monguor learners of Chinese must have correctly understood its meaning (that it was yao and not some other device that was the modal of necessity), indicating that this change did not originate in a perception error (e.g., reanalysis) (cf. Detges and Waltereit, 2002). That is, since a head-final

14 For basic word order, as for all other contact-induced features of the Xining dialect, the absence of diachronic data on the dialect precludes assigning precise dates to the emergence of particular features. However, since we know that the contact situation began to form in the early Ming (when Chinese immigration occurred in the late $14^{\text {th }}$ and early $15^{\text {th }}$ century) (cf. Section 3), the dialect's creole features cannot predate that period - although that does not necessarily mean that all of the creole features had emerged by then. It is entirely possible that some features, such as basic OV, emerged earlier (facilitated by an affinity with the superstrate), whilst others only developed later on as the dialect came to be used more widely and for a greater range of social functions.

15 However, the form need not be exclusively due to Monguor influence, as Amdo Tibetan, also spoken in the area, has a similar post-VP modal thang, which could also have contributed to the uptake of the form in Xining Mandarin (Dede, 1999a). 
modal of necessity yao did not exist in the target lexifier (though pre-verbal deontic yao had been in use since ancient Chinese; LaBarge, 2016), the existence of a head-final order in the Xining dialect can be traced to production errors, when in their own speech the indigenous peoples fell back upon the head-final syntax of their native language. This involved the introduction of a word order entirely alien to Chinese dialects (cf. Chappell and Peyraube, 2016), a mechanism of change which according to Heine (2008) is rare in comparison to that discussed above for the VP.

Meanwhile, the case for exclusively Mongolic substrate interference comes more straightforwardly from a borrowed ablative postpositon $s a$ in the Xining dialect, which is found in Monguor but not in the province's non-Mongolic substrate languages, such as Salar (Turkic) or Tibetan (Dede, 1999a). ${ }^{16}$

(29) no ni ha waimian sa qu-gei yi ge sa [Xining Mandarin] 1SG 2SG OBJ outside ABL go-BEN one CL PRT

'I will get one for you from outside.'

(30) Dare:sa jausa badzar kura sdana [Monguor] 'Setting out from here, you can get to town.' (based on Dede 1999a: 9)

Given the absence of a phonologically similar form in Chinese, the mechanism here could not have involved reordering of a Chinese ablative preposition (e.g., cong 'from' in 31 from a pre-nominal to a post-nominal position).
(31) Ta cong Beijing huilai-le
[Standard Mandarin]
3SG from Beijing return.come-ASP
'He returned from Beijing.'

Rather, Dede (1999a) quite reasonably treats this as a case of a phonological form that the Monguor imported into their version of the target language, contributing a form-meaning unit from the substrate language to the regional Chinese variety.

Next, with regard to the future marker lia (sometimes also realized as li), it is suggested that we have a mechanism that has been called 'pattern replication' (Matras and Sakel, 2007: 844-5) or 'functional transfer' (Siegel, 2008: 112)

16 A similar ablative form, ('A)sA, had emerged in Middle Mongolian ( $13^{\text {th }}$-early $15^{\text {th }}$ century) (Rybatzki, 2003: 67). It may thus have been used by Mongol speakers more widely during the early Ming than only by the ancestors of the modern Monguor. 
to the lexifier, which Siegel (2008) notes is common in the emergence of tensemodality-aspect in expanded pidgins and creoles. It concerns the particle $l i$, which was already present in the Chinese superstrate, being used as a modal particle during the preceding Yuan dynasty, predominantly to denote hyperbole and exclamatory mood, and sometimes interrogative mood (e.g., J.X. Zhang, 2005: 37; L. Wang, 2015: 46-7).

(32) zhe loushang hao liangkuai li [Yuan dynasty Chinese]
this upstairs very cool li 'Upstairs is really cool.' (Yueyanglou, L. Wang, 2015: 47, my gloss and translation - DB)

(33) Ni kan, ta chuan-zhe shenme yifu li? [Yuan dynasty Chinese] you look, 3SG wear-IPFV what clothes $l i$ 'You look, what is he wearing?!' (Qiangtou mashang, Chen 2014: 110 , after Tai Tian 2003, my gloss and translation - DB)

In terms of aspect, Chen (2014: 110) shows that li marks the existence of an ongoing state or activity.

(34) ta hai bu ren de wo li [Yuan dynasty Chinese] 3SG still NEG know DE 1 SG li

'He still does not recognize me.' (Chenzhou tiaomi, Chen, 2014: 110, my gloss and translation - DB)

The exclamatory/affirmative modal functions identified for Xining lia in Section 2 (cf. Bell, 2017) closely resemble those of Chinese $l i$ in these examples, but, importantly, Chinese $l i$ is not also used as a future marker (unlike lia in the Xining dialect).

Therefore, to explain the development of Xining lia as a future marker with dynamic predicates, it is helpful to consider the role of the substrate. In Mongolic languages, the aspectual class of the predicate plays a vital role in determining the temporal reference of the non-past marker $-N A$, and the distribution of - NA closely matches that of lia in Xining Mandarin. When Mongolic - NA occurs on non-stative (action) predicates, a future reading is derived, whilst with stative predicates, a present/atemporal reading is derived (e.g., Ujiyediin, 1998; Svantesson, 1991; Brosig, 2009; Binnick, 2011; cf. Åkerman, 2012: 27). This correspondence has not gone unnoticed in studies across the wider region. For instance, Lee-Smith (1996a: 878) identifies -NA as equivalent to -li (which corresponds to Xining -lia) in her study of the Sinitic language Tangwang (spoken 
in neighbouring Gansu province). Since aspectually conditioned future tense marking by clause-final particle lia/li is anomalous among Chinese dialects and because the stative/dynamic opposition determines the patterning of this function across a range of predicate types very similarly to in Mongolic (cf. Monguor examples (18) and (19)), Mongolic contact influence is a plausible explanation for this peculiar feature in the Xining dialect. Without assuming such a replication mechanism, it is difficult to explain why the same pattern of aspectually conditioned future marking is found for sentential particle lia as in Mongolic, given that this is not a feature of li/lia found in Mandarin dialects more widely across China.

Finally, let us consider the origin of the Xining dialect's SAY complementizer. The Ming Chinese language was not itself without a SAY complementizer, as shown in (35), which is from a vernacular Ming dynasty novel (Bai Niangzi Yong Zhen Leifeng Ta). (34) shows the SAY complementizer dao used before the complement clause.

Zhuren chi le yi jing lianmang [Ming Chinese]
Master eat ASP one surprise right-away
wen dao zuo shenme
ask DAO do what

"The master was surprised and immediately asked "What do you want?"' (Hwang, 2000: 148)

However, in view of its phonological form, the Xining dialect's complementizer fozho $(f o$ 'say' + imperfective $z h o$ ) is clearly derived instead from the dialect's own generic speech verb $f o$.

(36) na no ha qu ha hai mai ge fuxi [Xining Mandarin] then 1 SG TOP go COND still buy CL revision

ziliao fozho xiang-zho zho

'I think that if I go, I will still buy revision materials.' (Bell, 2018)

We saw above how the form (a fusion of SAY + IPFV) and the position of this device (following rather than preceding the complement clause) resembles that in Mongolic languages (cf. Monguor example 25). In addition, it can be noted that a corresponding Mongolic SAY complementizer exists in some of the earliest records of Mongolian, indicating that the age of the device in the Mongolic substrate predates the arrival of Chinese colonists in the early Ming. (37) is from the Secret history of the Mongols (a $13^{\text {th }}$ century colloquial 
Mongolian text), and shows kee- $n$ 'say' + converb functioning as a complementizer with a cognitive verb.

(37) 'Tere Qajar sayin[,] ed sayin' [Middle Mongolian]
DEM.DIST land good things good

$\begin{array}{llll}\begin{array}{l}\text { kee-gde-müy" } \\ \text { say-PASS-IPFV }\end{array} & \begin{array}{l}\text { kee-n } \\ \text { CMP }\end{array} & \begin{array}{l}\text { mede-jü } \\ \text { know-CVB.IPFV }\end{array} & \begin{array}{l}\text { Ögödey } \\ \text { NAME }\end{array} \\ \begin{array}{l}\text { qahan } \\ \text { Qa'an }\end{array} & \begin{array}{l}\text { jarliq } \\ \text { order }\end{array} & \begin{array}{l}\text { bol-urun... } \\ \text { become-CVB.PREP }\end{array}\end{array}$

'When Ögödei Qa'an learned that the land was reputedly good and the things [therein were also reputedly] good, he ordered as follows: “..." (lit: "knowing saying [the words] "that land [is] good, things [there are] good” are said'). (Street, 2013: 70, my gloss-DB)

Therefore, the mechanism here replicates a grammaticalisation pathway (speech verb to complementizer) which (37) shows had earlier taken place in the Mongolic substrate - resulting in a clause-final SAY complementizer in the Xining dialect that is anomalous among Chinese dialects both in terms of word order and form.

\section{$7 \quad$ Conclusion}

To conclude, this paper has considered the nature of creolization in Xining Mandarin. A previous account involving widespread rapid language shift by substrate populations in the early Ming was explored in Section 4, and this was argued to lack plausibility for a number of reasons, particularly the fact that the local non-Chinese speaking peoples, in particular the Monguor, were the majority population in the region, and their mother tongue remained necessary for intragroup communication. Instead, it was argued that the dialect originated in Ming gradual/fort creolization, similar to that found for European creoles along the West African coast. As in European creolization in West Africa, the Chinese colonizing presence involved the establishment of military fortifications in a land occupied by indigenous populations with whom the colonizers lacked a common language, but with whom they interacted for trade purposes. Distinctives of Chinese (as opposed to European) fort creolization were also considered, such as the Tusi 'native chieftain' system and the 
lessor role of interethnic marriage. Finally, in terms of the socio-historical conditions involved, it can be noted that the Xining dialect represents a type of contact scenario that occurred at many points across the Chinese frontier, and so the fort creolization model may also be applicable in understanding the origin of other Chinese dialects.

\section{Acknowledgement}

This research was supported by the Arts and Humanities Research Council (AHRC), as well as the Universities' China Committee in London (UCCL).

\section{References}

Adone, Dany. 1994. The acquisition of Mauritian creole. Amsterdam: John Benjamins. Åkerman, Vesa. 2012. Inflection of finite verbs in Mongghul. sIL Electronic Working Papers 3. Downloadable at https://www.sil.org/resources/publications/entry/49117 (accessed 10 July, 2020).

Arends, Jacques. 1993. Towards a gradualist model of creolization. In Francis Byrne, and John Holm (eds.), Atlantic Meets Pacific: A Global View of Pidginization and Creolization, 371-380. Amsterdam: John Benjamins.

Arends, Jacques. 1994. The socio-historical background of creoles. In Jacques Arends, Pieter Muysken, and Norval Smith (eds.), Pidgins and Creoles: An Introduction, 1524. Amsterdam: John Benjamins.

Arends, Jacques. 1995. Demographic factors in the formation of Sranan. In Jacques Arends (ed.), The Early Stages of Creolization, 233-285. Amsterdam:John Benjamins.

Arends, Jacques, and Adrienne Bruyn. 1994. Gradualist and developmental hypotheses. In Jacques Arends, Pieter Muysken and Norval Smith (eds.), Pidgins and Creoles: An Introduction, 111-120. Amsterdam: John Benjamins.

Bell, Daniel. 2017. Tense and mood marking in Xining Mandarin: An aspectual account of the particle lia. International Journal of Chinese Linguistics 4 (1): 62-93.

Bell, Daniel. 2018. Complementizers from verba dicendi in Chinese dialects: a view from Qinghai Mandarin. In Danqing Liu and Bingfu Lu (eds.), Yuyan Leixingxue Jikan 193-234. Beijing: Beijing Shijie Tushu Chuban Gongsi.

Bell, Daniel. 2019. Chinese possesses Japanese style scrambling: the case of Xining Mandarin. Journal of East Asian Linguistics 28 (2): 143-178.

Bickerton, Derek. 1988. Creole languages and the bioprogram. In Frederick J. Newmeyer (ed.), Linguistic theory: Extensions and Implications, 268-284. Cambridge: Cambridge University Press. 
Binnick, Robert I. 2011. The Past Tenses of the Mongolian Verb: Meaning and Use. Leiden: Brill.

Brosig, Benjamin. 2009. The function of the suffix -na in Khalkha Mongolian. Altai Hakpo 19: 87-112.

Byrne, Francis, and John Holm. 1993. Introduction: Perspectives on the Atlantic and Pacific... and beyond. In Francis Byrne and John Holm (eds.), Atlantic Meets Pacific: A Global View of Pidginization and Creolization, 1-24. Amsterdam: John Benjamins.

Chappell, Hilary. 2008. Variation in the grammaticalization of complementizers from verba dicendi in Sinitic languages. Linguistic Typology 12: 45-98.

Chappell, Hilary M. 2001. Synchrony and diachrony of Sinitic languages: A brief history of Chinese dialects. In Hilary Chappell (ed.), Sinitic Grammar, 3-28. Oxford: Oxford University Press.

Chappell, Hilary, and Alain Peyraube. 2016. Modality and mood in Sinitic. In Jan Nuyts and Johan Van Der Auwera (eds.), The Oxford Handbook of Modality and Mood. Oxford: Oxford University Press. Dor: 10.1093/oxfordhb/9780199591435.013.14.

Chaudenson, Robert. 1977. Toward the reconstruction of the social matrix of creole language. In Albert Valdman (ed.), Pidgin and Creole Linguistics, 259-276. Bloomington, IN: Indiana University Press.

Chen, Guangguo. 1997. Qinghai Zangzu Shi. Xining: Qinghai Minzu Chubanshe.

Chen, Shanqing. 2014. Miluo Xiangyu zhong de xu chengfen “[li] 里”, “[li] 俚” “[li] 哩”. Hunan Gongye Daxue Xuebao (Shehui Kexue Ban) 19 (6): 106-111.

Chen, Xinhai. 1996. Mingdai xing tunshubian yu Qinghai diming. Qinghai Minzu Xueyuan Xuebao 2: 44-49.

Cheng, Xianghui. 1980. Qinghai kouyu yufa sanlun. Zhongguo Yuwen 2 : 142-149.

Cui, Yonghong. 1988. Mingdai Qinghai hehuang diqu tuntian de fenbu he junhu de laiyuan. Qinghai Shehui Kexue 6: 90-97.

Cui, Yonghong. 2016. Mingdai Qinghai yinan lishi dili wenti kaozheng. Qinghai Minzu Daxue Xuebao 1: 79-84.

Cui, Yonghong, Dezu Zhang, and Changshun Du (eds.). 1999. Qinghai Tongshi. Xining: Qinghai Renmin Chubanshe.

Dardess, John W. 2003. Did the Mongols matter? Territory, power, and the intelligentsia in China from the northern Song to the early Ming. In Paul Jakov Smith and Richard von Glahn (eds.), The Song-Yuan-Ming Transition in Chinese History, 111-134. Cambridge: Harvard University Asia Center.

Dede, Keith. 1993. Language contact on the Qinghai-Gansu border area. Master's thesis, University of Washington.

Dede, Keith. 1999a. An ablative postposition in the Xining dialect. Language Variation and Change 11 (1): 1-17.

Dede, Keith. 1999b. Language Contact, Variation and Change: the Locative in Xining, Qinghai. PhD dissertation, University of Washington. 
Dede, Keith. 2003. The Chinese language in Qinghai. Studia Orientalia 95: 321-346.

Dede, Keith. 2016. Modal auxiliaries in Qīnghăi Chinese. In Pang-Hsin Ting and Samuel Hung-Nin Cheung (ed.), Studies in Chinese Linguistics, 551-564. T.T: Ng Chinese Language Research Centre, Institute of Chinese Studies, The Chinese University of Hong Kong.

Detges, Ulrich, and Richard Waltereit. 2002. Grammaticalization vs. reanalysis: A semantic-pragmatic account of functional change in grammar. Zeitschrift für Sprachwissenschaft 21 (2): 151-195.

Du, Xingzhou. 1995. Lun Xininghua li de xuci "lia" Qinghai Minzu Daxue Xuebao (Shehui Kexue Ban) 1: 56-61.

Dwyer, Arienne M. 1992. Altaic elements in the Línxìa dialect: Contact-induced change on the yellow river plateau. Journal of Chinese Linguistics 20 (1): 160-179.

Fang, Mei. 2006. Beijinghua-li 'shuo' de yufahua - cong yanshuo dongci dao congju biaoji Zhongguo Fangyan Xuebao 1: 107-121.

Gong, Yin. 1992. Zhongguo Tusi Zhidu. Kunming: Yunnan Renmin Chubanshe.

Hall, Robert A. 1962. The life cycle of pidgin languages. Lingua 11: 151-156.

Hancock, Ian. 1986. The domestic hypothesis, diffusion and componentiality: An account of Atlantic Anglophone creole origins. In Pieter Muysken and Norval Smith (eds.), Substrata versus Universals in Creole Genesis, 71-102. Amsterdam: John Benjamins.

Heine, Bernd. 2008. Contact-induced word order change without word order change. In Peter Siemund and Noemi Kintana (eds.), Language Contact and Contact Languages, 33-6o. Amsterdam: John Benjamins.

Huber, Magnus. 1999. Ghanaian Pidgin English in its West African Context: A Sociohistorical and Structural Analysis. Amsterdam: John Benjamins.

Hwang, Jya-Lin. 2000. Historical development of reported speech in Chinese. In Lisa J. Conathan, Jeff Good, Darya Kavitskaya, Alyssa B. Wulf and Alan C. L. Yu (eds.), Proceedings of the Twenty-sixth Annual Meeting of the Berkeley Linguistics Society, 145-156. Berkeley, CA: Berkeley Linguistics Society.

Jia, Wei. 2001. Ming zhong hou qi Qinghai hehuang diqu zangzu renkou shuliang kaocha. Qinghai Minzu Yanjiu: Shehui Kexue Ban 12 (3): 75-77.

Jia, Wei. 2012. Ming Qing Shiqi Hehuang Diqu Minzu Renkou Yanjiu. PhD dissertation, Lanzhou University.

Jia, Xiru. 1990. Dui hehuang hanyu jige yufa xianxiangde fenxi. Qinghai Minzu Xueyuan Xuebao 4: 37-44.

LaBarge, Robert Santana. 2016. The grammaticalization of 要 Yao and the future cycle from Archaic Chinese to Modern Mandarin. In Elly van Gelderen (ed.), Cyclical Change Continued, 395-418. Amsterdam: John Benjamins.

Lee-Smith, Mei W. 1996a. The Tangwang language. In Stephen A. Wurm, Peter Mühlhäusler and Darrell T. Tryon (eds.), Atlas of Languages of Intercultural Communication in the Pacific, Asia, and the Americas, 875-882. Berlin: Mouton de Gruyter. 
Lee-Smith, Mei W. 1996b. The Hezhou language. In Stephen A. Wurm, Peter Mühlhäusler and Darrell T. Tryon (eds.), Atlas of Languages of Intercultural Communication in the Pacific, Asia and the Americas, 865-874. Berlin: Mouton de Gruyter.

Li, Charles N. 1995. Language contact in China: Is Mandarin Chinese derived from a pidgin? In Jacek Fisiak (ed.), Linguistic Change under Contact Conditions, 131-148. Berlin: Walter de Gruyter.

Li, Jiansheng. 2010. Hanzu yimin yu hehuang diqu de renwen shengtai bianqian. Xibei Renkou 4: 67-72.

Limusishiden, and Keith Dede. 2012. The Mongghul experience: consequences of language policy shortcomings. International Journal of the Sociology of Language (215): 101-124. DOI: 10.1515/ijsl-2012-0031.

Liu, Minkuan, Ying Long, and Jiguang Wang, eds. 1993 [1595]. Xining Wei zhi. Xining: Qinghai Renmin Chubanshe.

Lu, Lanhua. 2011. Huangshui liuyu hanyu fangyan de xingcheng. Tianshui Shifan Xueyuan Xuebao 31 (6): $76-80$.

Luo, Guihua, and Yongjiu Gao. 20o6. Ming chao Xining wei de junshi shu fang yu zhengzhi guankong. Zhongguo Bianjiang Shi Di Yanjiu 16 (1): 66-77.

Matisoff, James A. 1991. Areal and universal dimensions of grammatization in Lahu. In Elizabeth Traugott and Bernd Heine (eds.), Approaches to Grammaticalization, 383453. Amsterdam: John Benjamins.

Matras, Yaron, and Jeanette Sakel. 2007. Investigating the mechanisms of pattern replication in language convergence. Studies in Language 31 (4): 829-865.

Meakins, Felicity. 2013. Mixed languages. In Peter Bakker and Yaron Matras (eds.), Contact Languages: A Comprehensive Guide, 159-228. Boston/Berlin: Walter De Gruyter.

Mufwene, Salikoko S. 2008. Language Evolution: Contact, Competition and Change. London: Continuum International Publishing Group.

Mufwene, Salikoko S. 2016. The emergence of creoles and language change. In Nancy Bonvillain (ed.), The Routledge Handbook of Linguistic Anthropology, 348-365. New York: Routledge.

Mühlhäusler, Peter. 1980. Structural expansion and the process of creolization. In Albert Valdman and Arnold Highfield (eds.), Theoretical Orientations in Creole Studies, 19-55. London: Academic Press.

Muysken, Pieter. 2016. Creole languages. Oxford Research Encyclopedia of Linguistics. Oxford: Oxford University Press. Dor: 10.1093/acrefore/9780199384655.013.68.

Muysken, Pieter, and Norval Smith. 1995. The study of pidgin and creole languages. In Jacques Arends, Pieter Muysken and Norval Smith (eds.), Pidgins and Creoles: An Introduction, 3-14. Amsterdam: John Benjamins.

Paul, Waltraud. 2002. Sentence-internal topics in Mandarin Chinese: The case of object preposing. Language and Linguistics 3 (4): 695-714.

Paul, Waltraud. 2015. New Perspectives on Chinese Syntax. Berlin: De Gruyter Mouton. 
Robinson, David. 2017. Why military institutions matter for Ming history. Journal of Chinese History 1 (2): 297-327. DOI: 10.1017/jch.2016.36.

Robinson, David M. 2004. Images of subject Mongols under the Ming dynasty. Late Imperial China 25 (1): 59-123.

Rossabi, Morris. 1998. The Ming and Inner Asia. In Denis Twitchett and Frederick W. Mote (eds.), The Cambridge History of Modern China, Volume 8: The Ming Dynasty, 1398-1644 Part 2. Cambridge: Cambridge University Press.

Rybatzki, Volker. 2003. Middle Mongol. In Juha Janhunen (ed.), The Mongolic Languages, 57-82. London: Routledge.

Sandman, Erika. 2018. Egophoricity in Wutun. In Simeon Floyd, Elisabeth Norcliffe and Lila San Roque (eds.), Egophoricity. Typological Studies in Language, 173-196. Amsterdam: John Benjamins.

Sankoff, Gillian, and Suzanne Laberge. 1973. On the acquisition of native speakers by a language. Kivung 6: 32-47.

Schram, Louis. 2006 [1954, 1957, 1961]. The Monguors of the Kansu-Tibetan Frontier Part I: Their Origin, History and Social Organization; Part II: Their Religious Life; Part III: Records of the Monguor Clans: History of the Monguors in Huangchung and the Chronicles of the Lu Family [with introductions by Juha Janhunen, Paul Neitpupski, Gray Tuttle, Keith Slater, Jeroom Heyndrickx, and Limusishiden and Kevin Stuart]. Charles Kevin Stuart (ed.). Xining City: Plateau Publications.

Serruys, Henry. 1955. The Mongols of Kansu During the Ming. In Mélanges chinois et bouddhiques, 215-343. Bruxelles: L'Institut Belge des Hautes Études Chinoises.

Serruys, Henry. 1980. The Mongols in China During the Hung-wu Period (1368-1398). Vol. 11, Mélanges Chinois et Bouddhiques. Bruxelles: L'Institut Belge des Hautes Études Chinoises.

Shnukal, Anna, and Lynell Marchese. 1983. Creolization of Nigerian Pidgin English: A progress report. English World-Wide 4 (1): 17-26. DoI: https://doi.org/10.1075/ eww.4.1.03shn.

Siegel, Jeff. 2008. The Emergence of Pidgin and Creole Languages. Oxford: Oxford University Press.

Slater, Keith W. 2003. A Grammar of Mangghuer: a Mongolic Language of China's Qinghai-Gansu Sprachbund. London: RoutledgeCurzon.

Street, John. 2013. On Quotation in Middle Mongolian: The verb ke(m)e-'to say', Mongolia Society Occasional Paper 27. Bloomington, Indiana: The Mongolia Society.

Su, Xian, Yu Wang, and Zhong Ma, eds. 1993 [1657]. Xining zhi. Xining: Qinghai Renmin Chubanshe.

Svantesson, Jan-Olof. 1991. Tense, mood and aspect in Mongolian. Lund Working Papers in Linguistics 38: 189-204.

Szonyi, Michael. 2017. The Art of Being Governed: Everyday Politics in Late Imperial China. Princeton: Princeton University Press. 
Tan, Hongbing, Huifang Zhou, Wenbo Rao, Wenjie Zhang, and Na Kong. 2012. Geochemical constraints on seasonal recharge of water and major dissolved solutes in the Huangshui River, China. Chinese Journal of Geochemistry $3^{1}$ (2): 155-164.

Thomason, Sarah G. 2001. Language Contact. Edinburgh: Edinburgh University Press.

Thomason, Sarah G., and Terrence Kaufman. 1988. Language Contact, Creolization, and Genetic Linguistics. Berkeley: University of California Press.

Tong, Tao. 2008. The Silk Roads Of The Northern Tibetan Plateau During The Early Middle Ages (From The Han To Tang Dynasty) As Reconstructed From Archaeological And Written Sources. PhD dissertation, Universität Tübingen.

Tuttle, Gray. 2006. The Middle Ground: The Monguor Place in History, between China and Tibet. In Charles Kevin Stuart (ed.), The Monguors of the Kansu-Tibetan Frontier Part I: Their Origin, History and Social Organization; Part II: Their Religious Life; Part III: Records of the Monguor Clans: History of the Monguors in Huangchung and the Chronicles of the Lu Family, 37-43. Xining City: Plateau Publications.

Twitchett, Denis, and Tilemann Grimm. 1988. The Cheng-t'ung, Ching-t'ai, and T'ienshun reigns, 1436-1464. In Frederick W. Mote and Denis Twitchett (eds.), The Cambridge History of China, vol. vII, part 1: The Ming Dynasty, 1368-1644, 305-42. Cambridge: Cambridge University Press.

Ujiyediin, Chuluu. 1998. Studies on Mongolian Verb Morphology. PhD dissertation, University of Toronto.

Velupillai, Viveka. 2015. Pidgins, Creoles and Mixed Languages. Amsterdam: John Benjamins.

Wadley, Stephen. 1987. A Translation of the "Lao Qida" and Investigation into Certain of its Syntactic Structures. PhD dissertation, University of Washington.

Walczyński, Marcin. 2012. A Living Language: Selected Aspects of Tok Pisin in the Press (on the Basis of Wantok Newspaper). Nysa: PWSZ w Nysie.

Wang, Li. 2015. Yuan Quxuan Binbai Gantan Ju Yanjiu. PhD dissertation, Lanzhou University.

Wang, Shuangcheng. 2012. Xining fangyan de jieci leixing. Zhongguo Yuwen 5: $469-478$.

Wang, Shuangcheng, and Keith Dede. 2016. Negation in the Xīníng dialect. Language and Linguistics 17 (3): 407-429. DOI: 10.1177/1606822X15586686.

Wei, Luo. 2018. A preliminary study of Mongol costumes in the Ming dynasty. Social Sciences in China 39 (1): 165-185. DOI: 10.1080/02529203.2018.1414417.

Wei, Shiyou. 2011. Ming Qing shiqi Qinghai diqu de chama maoyi. Qinghai Shifan Daxue Xuebao (Zhexue Shehui Kexue Ban) 33 (1): 56-9.

Yan, Bo. 2012. Mingchu Taomin Hehuang diqu de jianghuai yimin yanjiu - jiyu yimin qunti leixing, laiyuan di he shuliang de kaocha. Lanzhou Xuekan 12: 37-42.

Yang, Jing. 2009. Qinghai hanyu fangyan sov jushi yanjiu zongshu. Yuwen Wenxue 2: $114-116$. 
Zhang, Ansheng. 2007. Xining Hui min hua de yinyu biaoji "shuozhe", "shuo". Zhongguo Yuwen 4: 343-356.

Zhang, Chengcai. 1992. Shilun Qinghai hanyu fangyan de xingcheng. Qinghai Shehui Kexue 1: 69-77.

Zhang, Jinkui. 2007. Mingdai Weisuo Junhu Yanjiu. Beijing: Xianzhuang Shuju.

Zhang, Junxiang. 2005. Ningwu fangyan zhong de zhuci "li". Xinzhou Shifan Xueyuan Xuebao 21 (1): 37-39.

Zhang, Meng, and Weizhen Wang. 2012. Qinghai fangyan yuqici de yuyong fenxi. Shidai Jiaoyu 3: 187-188.

Zhou, Qingsheng. 2013. List of languages in China. In Li Yuming (ed.), The Language Situation in China, 401-404. Berlin: Walter de Gruyter. 